\title{
Penerapan Aplikasi Manifes Penumpang Dan Kendaraan Di Pelabuhan Penyeberangan Batulicin Kalimantan Selatan.
}

\author{
Chairul I.Ilham ${ }^{1)-}$ Bambang S. ${ }^{2)}$ Atiqoh.AS ${ }^{3)}$ \\ Poltek Trans SDP Palembang \\ Email:
}

\begin{abstract}
Applying passenger and vehicles manifest aplication nowdays is a must. The function is to improve our service and safety of the passengers and vehicles that will load in to the ship. This aplication is an aplication made by using Visual Basic 6.0 which designed to make the process of making the manifest of passengers and vehicles easier and clustured by it's type and function. This aplication use the date of the passenger and vehicles in Batulicin Harbour using the computerization system by making the form to input the data of passenger and vehicles. The data are : 1) Identity of passenger and vehicles 2) identity of vehicles and the crews; by designing the program using Visual Basic 6.0 by two steps, which are makeing the database and the design of aplication page. They are Login page, Main page, User page, Data page, Class of passenger and vehicles page, Ticket amount page, and Ticket booking page. The result from this program is to make the operator easier to archiving the document and monitoring the sold tickets and also to avoid the duplication of service.
\end{abstract}

\section{A. PENDAHULUAN}

Pelabuhan Penyeberangan Batulicin merupakan salah satu Pelabuhan yang ada di Kabupaten Tanah Bumbu yang mempunyai peranan penting dalam meningkatkan perkembangan perekonomian khususnya dalam mengembangkan perekonomian di Kecamatan Batulicin, Kabupaten Tanah Bumbu. Pelabuhan Penyeberangan Batulicin ini dikelola oleh PT. ASDP Indonesia Ferry (Persero) Cabang Batulicin dan memiliki 2 (dua) lintasan yaitu lintasan komersil Batulicin - Tanjung Serdang yang dilayani oleh 7 kapal penyeberangan dengan jarak lintas 2,5 mil dan lintasan Perintis Batulicin - Garongkong yang dilayani oleh 1 kapal penyeberangan dengan jarak lintas 473,58 mil.

Dalam upaya meningkatkan keamanan, kenyamanan dan keselamatan angkutan penyeberangan maka identitas para pengguna jasa sangatlah dibutuhkan baik pengguna jasa pejalan kaki maupun kendaraan beserta penumpang dan barang muatan yang dimuat dalam kendaraan. Identitas ini nantinya dipergunakan untuk pengisian daftar manifes penumpang dan kendaraan di Pelabuhan Penyeberangan Batulicin. Selain itu, data identitas penumpang dan kendaraan juga berguna bagi PT. ASDP selaku pengelola pelabuhan untuk pendataan produktifitas penumpang dan kendaraan harian angkutan penyeberangan.

Dari hasil survei dan pengamatan yang dilakukan selama kegiatan dilapangan, diketahui bahwa kondisi saat ini para pengguna jasa Pelabuhan Penyeberangan Batulicin tidak diminta untuk mengisi data manifes pada saat pembelian tiket, karena jarak tempuh penyeberangan yang relatif pendek dan selama ini dianggap tidak diperlukannya daftar tersebut karena penyeberangan lintas Batulicin - Tanjung Serdang tidak menggunakan SPB, melainkan Surat Izin Gerakan Bandar yang berlaku selama 7 hari. Hal ini bertentangan dengan Peraturan Menteri Perhubungan Nomor PM 25 tahun 2016 tentang Daftar Penumpang Dan Kendaraan Angkutan Penyeberangan bahwa setiap kapal angkutan penyeberangan yang akan berlayar wajib memiliki Surat Persetujuan Berlayar, dan untuk mendapatkan Surat Persetujuan Berlayar tersebut maka pihak pelabuhan wajib melampirkan daftar penumpang dan kendaraan diatas 
kapal angkutan penyeberangan. Selain itu Pelabuhan Penyeberangan Batulicin ini hanya memiliki 1 (satu) loket untuk melayani pengguna jasa pejalan kaki maupun kendaraan golongan I hingga golongan IX. Hal ini sangat membahayakan para pengguna jasa terkhusus para pengguna jasa pejalan kaki.

Berdasarkan kondisi yang ada, kami merasa perlu membuat suatu rencana perancangan aplikasi manifes penumpang dan kendaraan angkutan penyeberangan agar kegiatan pendataan dapat dilakukan dengan hasil yang tertata rapi dan data penumpang dan kendaraan dapat dikelompokkan secara otomatis oleh aplikasi.

Berdasarkan pengamatan yang telah dilakukan di lokasi penelitian, maka dalam penulisan ini ada beberapa issue yang menurut hemat kami belum memenuhi beberapa harapan dan perlu dikaji dan diberikan solusi penyelesaiannya, yaitu :

1. Kondisi keselamatan pengguna jasa pada saat pembelian tiket di Pelabuhan Penyeberangan Batulicin

2. Sistem pendataan manifes penumpang dan kendaraan yang ada di Pelabuhan Penyeberangan Batulicin sesuai dengan Peraturan Menteri Perhubungan Republik Indonesia No 25 tahun 2016 tentang daftar penumpang dan kendaraan angkutan Penyeberangan

3. Perlu pembuatan aplikasi manifest penumpang dan kendaraan di Pelabuhan Penyeberangan Batulicin

\section{B. LANDASAN TEORI}

Peraturan Menteri Perhubungan Nomor PM 25 tahun 2016 tentang Daftar Penumpang dan Kendaraan Angkutan Penyeberangan

a. Pasal 3

Daftar penumpang dan kendaraan di atas kapal angkutan penyeberangan terdiri atas:

1. Penumpang pejalan kaki;

2. Penumpang pada kendaraan;

3. Kendaraan golongan I s/d IX.

b. Pasal 4 ayat (3)

Data identitas penumpang paling sedikit memuat:

1. Nama;

2. Jenis kelamin;

3. Usia;

4. Alamat (domisili); dan

5. Nomor paspor penumpang asing.

c. Pasal 6

Pengemudi kendaraan wajib menyampaikan informasi kepada penumpang mengenai larangan penumpang berada dalam kendaraan selama pelayaran, sebelum memasuki pelabuhan.

d. Pasal 7

Pengemudi kendaraan yang menggunakan jasa angkutan penyeberangan terdiri atas pengemudi kendaraan perorangan untuk angkutan penumpang dan untuk angkutan barang.

e. Pasal 12 ayat (1),(2) dan (3)

(1) Pengemudi sebelum membeli tiket wajib menyerahkan manifes tersebut kepada petugas loket sebagai persyaratan membeli tiket,

(2) Pengemudi yang tidak menyerahkan manifes tersebut tidak akan dilayani pembelian tiket,

(3) Manifes tersebut sekurang-kurangnya memuat:

- Nama penumpang

- Jenis kelamin 
- Usia

- Alamat (kota domisili)

- Nomor kendaraan bermotor

- Jenis/golongan

Untuk mendukung dasar hukum yang sudah ada, maka perlu adanya teori yang terkait dalam penulisan ini:

1. Visual basic

Menurut (Jubilee 2017) visual basic adalah bahasa pemrograman yang mudah dipelajari dan di peraktikan. Program yang dihasilkan berupa aplikasi yang bekerja pada sistem operasi windows. Program ini dikembangkan dalam sebuah IDE (Intergrated Development Environtment) sehingga pengguna tidak perlu bersusah payah menuliskan kode ke program. Aplikasi ini juga merupakan aplikasi berbasis Graphical User Interface sehingga mempunyai antarmuka dengan tombol, jendela, menu dan toolbar seperti pada Microsoft word.

\section{Bahasa pemrograman}

Menurut (Jubilee, 2017) bahasa pemrograman atau bahasa computer adalah instruksi standar untuk memerintah computer. Bahasa pemrograman ini merupakan suatu himpunan dari aturan sintaks dan sistematik yang dipakai untuk mendefinisikan program computer. Bahasa ini memungkinkan seorang programmer dapat menentukan secara persis data mana yang akan diolah oleh komputer, sebagaimana data ini akan disimpan/diteruskan, dan jenis langkah apa secara persis yang akan diambil dalam berbagai situasi.

\section{Form designer}

Menurut (Eri Dkk, 2017) form designer adalah sebuah window yang dapat digunakan untuk mengatur tampilan aplikasi yang akan kita buat, atau dengan kata lain sebagai tempat untuk mendesain sebuah form. Dalam mendesign sebuah form, kita juga harus mengenal istilah-istilah yang digunakan dalam visual basic 6.0 seperti:

a. Event yaitu merupakan aktivitas yang terjadi saat menggunakan aplikasi. Event terjadi karena adanya tindakan dari pemakai, seperti klik mouse atau penggunaan keyboard. Namun, event dapat juga terjadi karena adanya pengaturan oleh timer atau oleh aplikasi itu sendiri.

$b$. Properti yaitu sebagai bagian yang membangun sebuah objek. Properti ini sangat menentukan objek yang sedang dibuat. Kita dapat menyamakan sebuah objek dengan seorang manusia, sedangkan properti lainnya dapat kita samakan dengan namanya, tingginya, beratnya, jenis kelamin dan sebagainya.

c. Prosedur yaitu sekumpulan kode rutin yang ditulis dalam satu blok tersendiri. Blok tersebut hanya dieksekusi jika judul atau namanya dipanggil.

\section{Microsoft access}

Menurut (Junindar, 2010) Microsoft Access 2010 adalah sebuah perangkat lunak pengolah basis data yang berjalan dibawah sistem operasi Windows. Microsoft Access merupakan bagian dari paket program Microsoft Office yang memang dikhususkan untuk pengolah basis data. Microsoft Access 2010 memiliki beberapa fitur-fitur terbaru yaitu:

a. Quick Start Fields

b. Menu and Ribbon

c. Application Parts

d. Office Themes

e. Calculate Fields

f. Data Bars and Conditional Formatting 


\section{g. Navigation Form \\ h. Macro}

\section{Perancangan Bagan Alur Sistem}

Perancangan bagan alur sistem ini berfungsi untuk mengetahui bagaimana sistem kerja diri aplikasi yang direncanakan,dan data apa saja yang dibutuhkan untuk dimuat dalam aplikasi tersebut serta data apa yang dapat kita peroleh dari aplikasi tersebut. Berikut gambar bagan alur sistem aplikasi manifes penumpang dan kendaraan yang direncanakan:

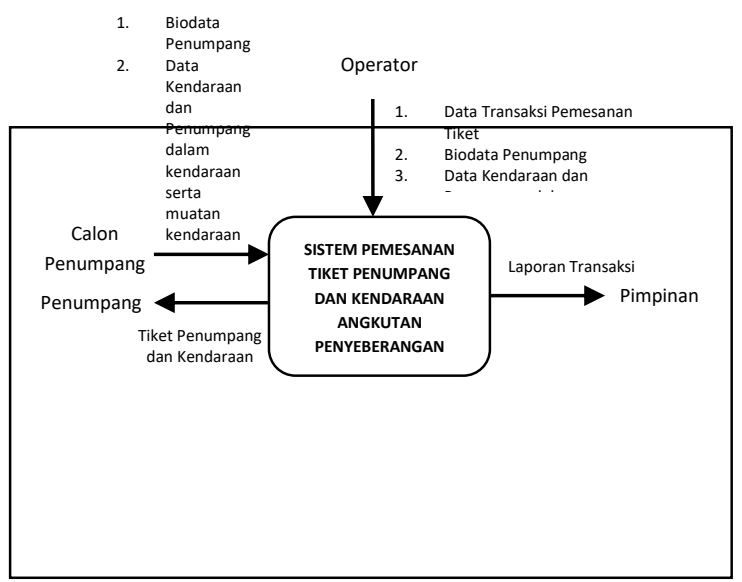

Sumber: Hasil Analisa, 2018

\section{Bagan Alur Sistem Pemesanan Tiket Angkutan Penyeberangan}

Dari diagram diatas maka dapat kita ketahui bahwa untuk mendapatkan tiket angkutan penyeberangan, calon penumpang pejalan kaki dan pengguna kendaraan harus memberikan informasi berupa biodata penumpang yang kemudian dicatat oleh operator dalam sebuah aplikasi manifes penumpang dan kendaraan angkutan penyeberangan yang kemudian data tersebut digunakan untuk dilaporkan kepada pimpinan pelabuhan dan dipergunakan sebagaimana mestinya.

\section{Perancangan Sistem}

Perancangan sistem adalah adalah gambaran dari proses alur pembuatan aplikasi yang akan dibuat. Tujuan perancangan ini adalah untuk keperluan proses pembelian tiket penumpang dan kendaraan di Pelabuhan Penyeberangan Batulicin. Dimulai dengan perancangan sistem. Gambaran umum perancangan dapat ditunjukkan pada gambar berikut:

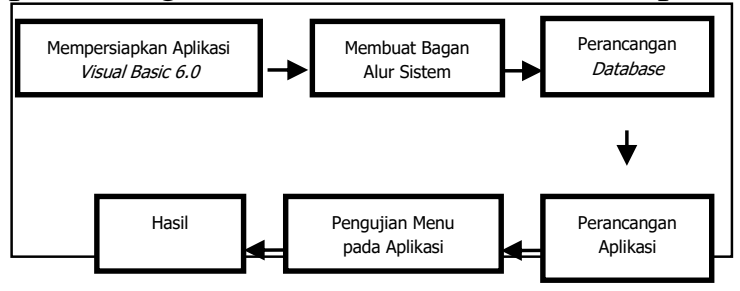

Sumber: Hasil Analisa, 2018

\section{Rancangan Sistem Aplikasi Manifes Penumpang dan Kendaraan}

\section{Flowchart Program}

Pada flowchart yang dibuat akan menjelaskan alur dari aplikasi manifes penumpang dan kendaraan angkutan penyeberangan di Pelabuhan Penyeberangan Batulicin Provinsi 
Kalimantan Selatan. Dalam flowchart tersebut akan dijelaskan konfigurasi input/output data yang dihasilkan masing-masing menu dan kemudian akan di input kedalam database. Berikut flowchart aplikasi manifes penumpang dan kendaraan yang dibuat:

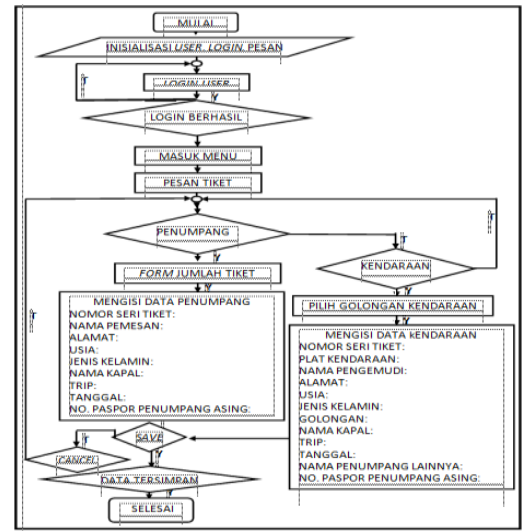

Sumber: Hasil Analisa, 2018

\section{FLOWCHART PROGRAM}

V.1 Diagram Penggunaan Aplikasi

Diagram penggunaan aplikasi ini meliputi cara pengoperasian aplikasi manifes penumpang dan kendaraan angkutan penyeberangan agar dapat dijadikan petunjuk bagi pengguna aplikasi dalam menggunakan aplikasi ini. Berikut diagram penggunaan aplikasi manifes penumpang dan kendaraan angkutan penyeberangan:

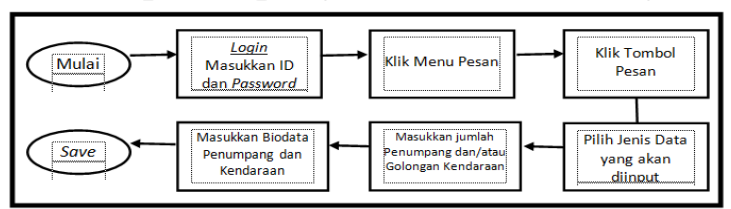

Sumber: Hasil Analisa, 2018

\section{Pemecahan Masalah}

\section{Diagram Penggunaan Aplikasi}

\section{VI.1 Pembuatan Database}

Perancangan database meliputi pembuatan tabel yang akan digunakan pada aplikasi manifes penumpang dan kendaraan. Database yang digunakan adalah Microsoft Access. Berikut cara membuat database pada visual basic :

1. Instal aplikasi visual basic.

2. Buka program visual basic.

3. Klik menu Add-Ins.

Klik visual data manager, dan akan muncul gambar seperti di bawah ini.

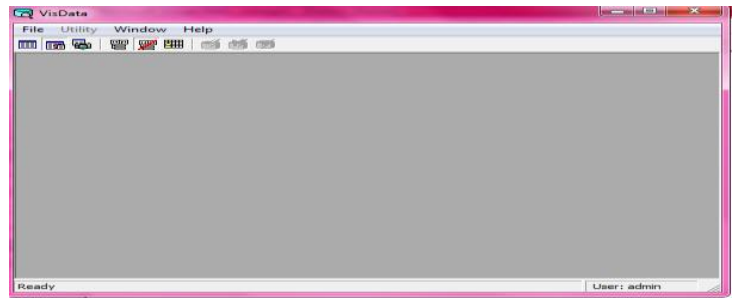

Sumber: Hasil Analisa, 2018

\section{Visual data}

4. Pilih file lalu New.

5. Pilih Microsoft Access lalu pilih versi $7.0 \mathrm{mdb}$.

6. Beri nama file dan lokasi penyimpanan data, nama file disimpan dengan nama Dbase.mdb, kemudian pilih save. 
Kemudian barulah kita membuat database yang akan dirancang untuk aplikasi manifes penumpang dan kendaraan sebagai berikut :

1. Database User

Sumber: Hasil Analisa, 2018

\begin{tabular}{|}
\begin{tabular}{|l|l|l|}
\hline USERNAME & PASSWORD & ACCOUNTTY - \\
\hline Atiqoh Astarin & 12345 & Admin \\
\hline User 1 & 12345 & User \\
\hline User 2 & 12345 & User \\
\hline
\end{tabular}
\end{tabular}

\section{Database user}

Database User pada aplikasi manifes penumpang dan kendaraan digunakan untuk kegiatan menambahkan akun bagi para petugas loket, sehingga masing-masing petugas memiliki data masing-masing.

2. Database Penumpang Pejalan Kaki

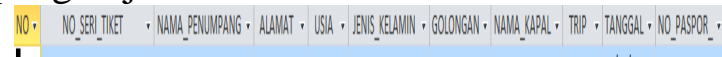

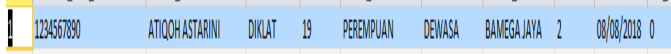

Sumber : Hasil Analisa, 2018

\section{Database Penumpang Pejalan Kaki}

Database penumpang pada aplikasi manifes penumpang dan kendaraan digunakan sebagai hasil rekapitulasi dari data penumpang Pejalan Kaki yang telah diinput sebelumnya.

3. Database Kendaraan

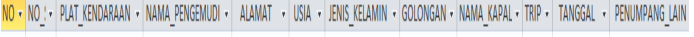

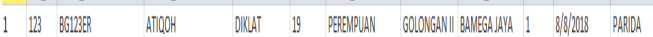

Sumber : Hasil Analisa, 2018

\section{Database Kendaraan}

Database kendaraan pada aplikasi manifes penumpang dan kendaraan digunakan sebagai hasil rekapitulasi dari data kendaraan yang telah diinput sebelumnya.

\section{V.2 Pembuatan Design}

Pembuatan Design meliputi pembuatan tampilan pada aplikasi manifes penumpang dan kendaraan. Aplikasi yang digunakan untuk membuat design yaitu visual basic 6.0. Untuk tahapan-tahapan yang harus dilakukan dalam pembuatan design pada aplikasi manifes penumpang dan kendaraan dapat dilihat pada Lampiran II.

Berikut design yang telah dibuat untuk aplikasi manifes penumpang dan kendaraan :

1. Design Halaman Awal

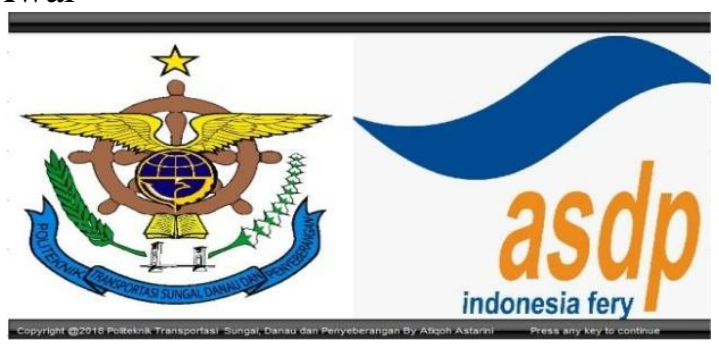

Sumber : Hasil Analisa, 2018

\section{Design Halaman Awal}

Design halaman awal pada aplikasi manifes penumpang dan kendaraan merupakan tampilan awal yang akan muncul ketika aplikasi dijalankan. 


\section{Design Halaman Login}

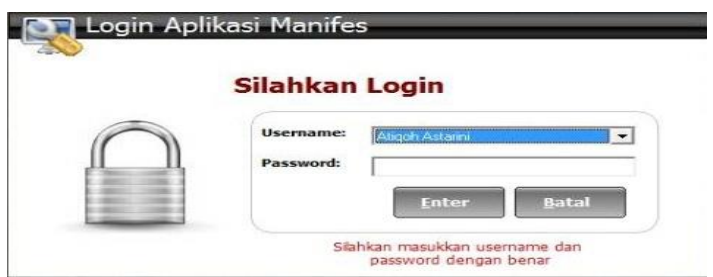

Sumber : Hasil Analisa, 2018

\section{Design Halaman Login}

Design halaman login pada aplikasi manifes penumpang dan kendaraan merupakan tampilan yang digunakan untuk mengakses menu-menu yang ada yaitu dengan cara memasukkan username dan password.

3. Design Halaman Utama

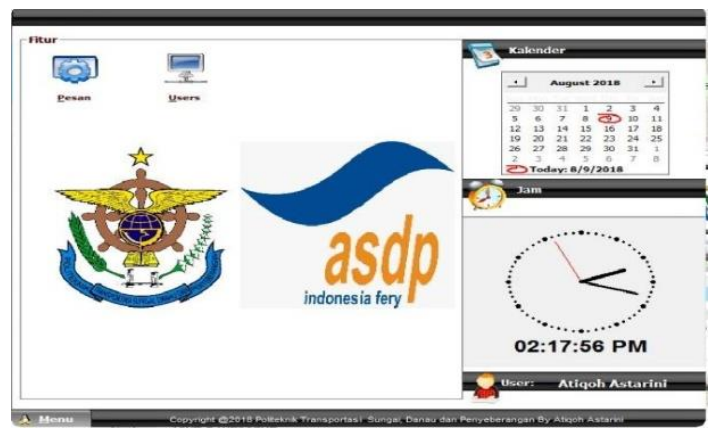

Sumber : Hasil Analisa, 2018

\section{Design Halaman Utama}

Design halaman awal pada aplikasi manifes penumpang dan kendaraan merupakan tampilan awal yang berisi menu-menu yang dapat digunakan seperti menu pemesanan tiket ataupun pengaturan $u s e r / a k u n$ pengguna.

4. Design Halaman Users

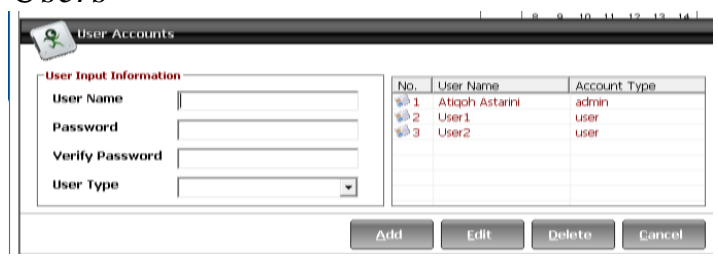

Sumber : Hasil Analisa, 2018

\section{Design Halaman Users}

Design halaman users pada aplikasi manifes penumpang dan kendaraan merupakan tampilan menu user yang berfungsi untuk mengatur password ataupun username operator ataupun untuk membuat akun baru. 
5. Design Halaman Daftar Penumpang dan Kendaraan

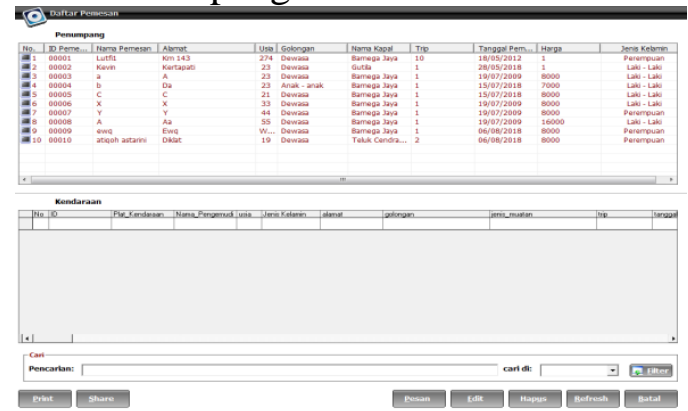

Sumber : Hasil Analisa, 2018

\section{Design Halaman Daftar Penumpang dan Kendaraan}

Design halaman Daftar Penumpang dan Kendaraan pada aplikasi manifes penumpang dan kendaraan merupakan tampilan menu pesan yang berfungsi untuk menampilkan daftar penumpang dan kendaraan yang sudah membeli tiket. Halaman ini juga memuat menu berupa tombol untuk menghapus data, merefresh data, ataupun mengedit data yang sudah ada. Namun menu-menu ini hanya dapat digunakan oleh admin, sedangkan untuk users tidak dapat menggunakan menu-menu tersebut.

6. Design Halaman Golongan

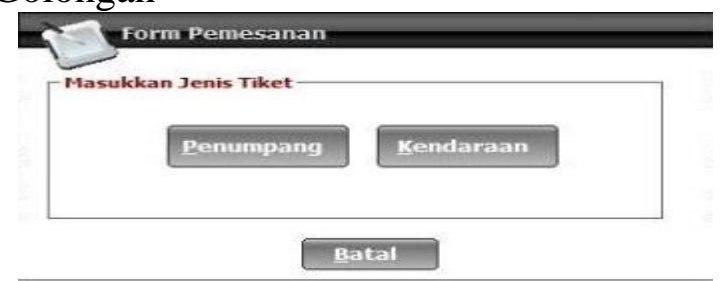

Sumber : Hasil Analisa, 2018

\section{Design Halaman Golongan}

Design halaman golongan pada aplikasi manifes penumpang dan kendaraan merupakan tampilan menu yang berfungsi untuk menampilkan pilihan data yang akan di masukkan.

7. Design Halaman Jumlah Tiket Penumpang Pejalan Kaki

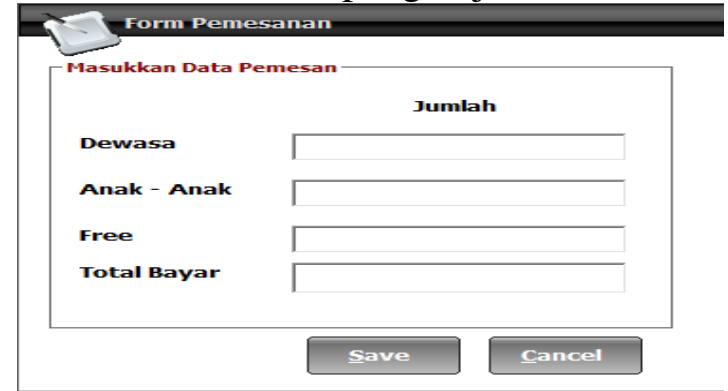

Sumber : Hasil Analisa, 2018

\section{Design Halaman Jumlah Penumpang Pejalan Kaki}

Design halaman jumlah penumpang pejalan kaki pada aplikasi manifes penumpang dan kendaraan merupakan tampilan untuk memasukkan berapa banyak tiket yang akan dibeli oleh 
penumpang yang kemudian akan terkalkulasi secara otomatis berapa jumlah uang yang harus dibayarkan oleh pengguna jasa.

8. Design Halaman Golongan Kendaraan

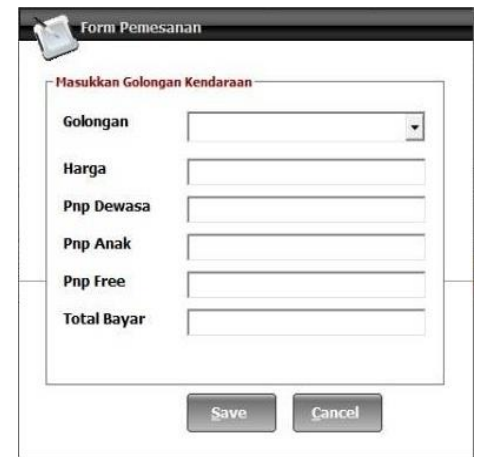

Sumber : Hasil Analisa, 2018

\section{Design Halaman Golongan Kendaraan}

Design halaman golongan kendaraan pada aplikasi manifes penumpang dan kendaraan merupakan tampilan untuk memasukkan jenis tiket kendaraan yang akan dibeli oleh penumpang yang kemudian akan menampilkan harga tiket yang harus di bayar oleh pengguna jasa secara otomatis.

9. Design Halaman Golongan Penumpang

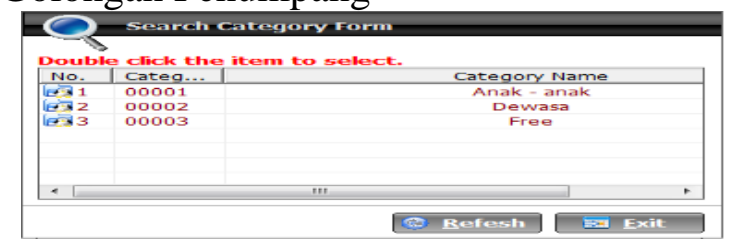

Sumber : Hasil Analisa, 2018

\section{Design Halaman Golongan Penumpang}

Design halaman golongan penumpang pada aplikasi manifes penumpang dan kendaraan merupakan tampilan untuk memasukkan jenis tiket yang akan dibeli oleh pengguna jasa.

10. Design Halaman Pemesanan Penumpang

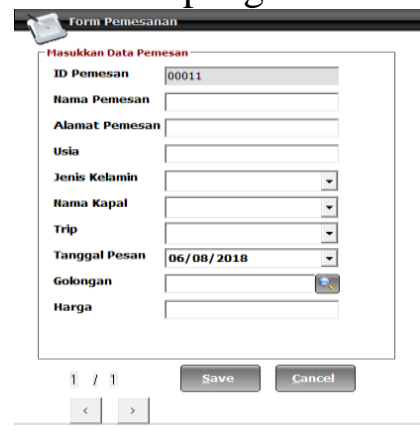

Sumber : Hasil Analisa, 2018

\section{Design Halaman Pemesanan Penumpang}

Design halaman pemesanan penumpang pada aplikasi manifes penumpang dan kendaraan merupakan tampilan untuk memasukkan biodata pengguna jasa pejalan kaki yang kemudian disimpan kedalam database.

11. Design Form Pemesanan Kendaraan 


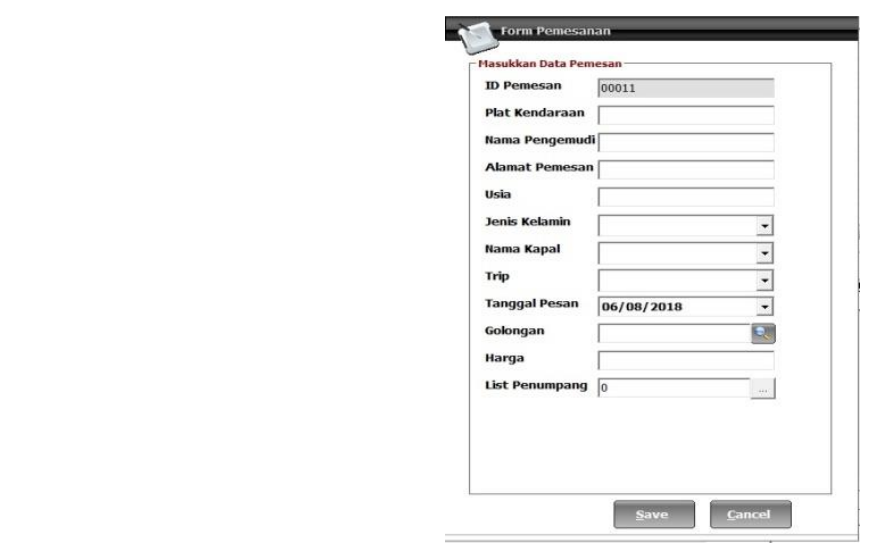

Sumber : Hasil Analisa, 2018

\section{Design Halaman Pemesanan Kendaraan}

Design halaman pemesanan kendaraan pada aplikasi manifes penumpang dan kendaraan merupakan tampilan untuk memasukkan data kendaraan beserta penumpang dan muatan yang diangkut yang kemudian disimpan kedalam database.

12. Design Halaman Pemesanan Penumpang Pada Kendaraan

Sumber : Hasil Analisa, 2018

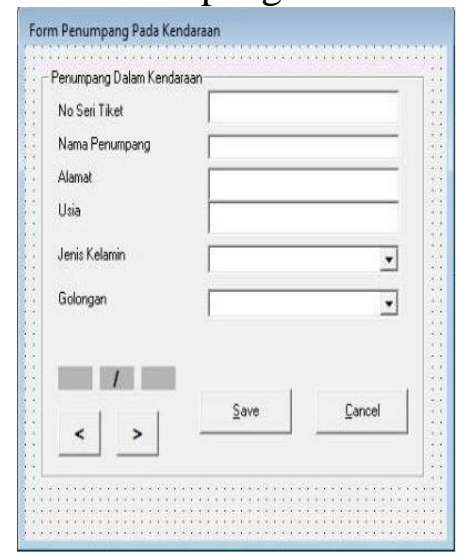

Design Halaman Pemesanan Penumpang Pada Kendaraan

Design halaman pemesanan penumpang pada kendaraan yang terdapat pada aplikasi manifes penumpang dan kendaraan merupakan tampilan untuk memasukkan biodata penumpang yang berada dalam kendaraan yang kemudian disimpan kedalam database.

\section{V.3 Validasi Aplikasi}

Untuk memastikan apakah aplikasi yang sudah dibuat dapat berjalan dengan benar, maka perlu dilakukannya proses ujicoba terhadap menu-menu yang ada pada aplikasi tersebut. Dalam melakukan percobaan tersebut maka dapat dilakukan dengan metode whitebox dan blackbox.

Pada metode ujicoba whitebox merupakan ujicoba aplikasi yang dapat dilihat dari algoritma atau flowchart aplikasi yang telah dibuat, sedangkan metode ujicoba blackbox yaitu dengan memperhatikan menu atau tombol-tombol yang tersedia dalam aplikasi tersebut. Untuk itu, berikut adalah metode ujicoba blackbox pada aplikasi manifes penumpang dan kendaraan:

\section{Validasi Aplikasi Dengan Metode Blackbox}




\begin{tabular}{|c|c|c|c|c|}
\hline $\begin{array}{l}\mathbf{N} \\
\mathbf{0}\end{array}$ & $\begin{array}{l}\text { Perco } \\
\text { baan }\end{array}$ & $\begin{array}{c}\text { Halam } \\
\text { an } \\
\text { Percob } \\
\text { aaan }\end{array}$ & Tujuan & Hasil \\
\hline $\begin{array}{l}\text { ( } \\
1 \\
)\end{array}$ & (2) & (3) & (4) & (5) \\
\hline 1 & $\begin{array}{l}\text { Tekan } \\
\text { tombo } \\
\text { 1 pada } \\
\text { keybo } \\
\text { ard }\end{array}$ & $\begin{array}{l}\text { Halama } \\
\text { n Awal }\end{array}$ & $\begin{array}{l}\text { Halama } \\
\text { n Login }\end{array}$ & $\begin{array}{c}\text { Berha } \\
\text { sil }\end{array}$ \\
\hline 2 & $\begin{array}{l}\text { Klik } \\
\text { Enter }\end{array}$ & $\begin{array}{l}\text { Halama } \\
\text { n Login }\end{array}$ & $\begin{array}{l}\text { Halama } \\
\mathrm{n} \\
\text { Utama }\end{array}$ & $\begin{array}{c}\text { Berha } \\
\text { sil }\end{array}$ \\
\hline 3 & $\begin{array}{l}\text { Klik } \\
\text { Batal }\end{array}$ & $\begin{array}{l}\text { Halama } \\
\text { n Login }\end{array}$ & $\begin{array}{l}\text { Halama } \\
\text { n Awal }\end{array}$ & $\begin{array}{c}\text { Berha } \\
\text { sil }\end{array}$ \\
\hline 4 & $\begin{array}{l}\text { Klik } \\
\text { Pesan }\end{array}$ & $\begin{array}{l}\text { Halama } \\
\mathrm{n} \\
\text { Utama }\end{array}$ & $\begin{array}{l}\text { Halama } \\
\mathrm{n} \text { daftar } \\
\text { penump } \\
\text { ang dan } \\
\text { kendara } \\
\text { an }\end{array}$ & $\begin{array}{c}\text { Berha } \\
\text { sil }\end{array}$ \\
\hline 5 & $\begin{array}{l}\text { Klik } \\
\text { Users }\end{array}$ & $\begin{array}{l}\text { Halama } \\
\mathrm{n} \\
\text { Utama }\end{array}$ & $\begin{array}{l}\text { Halama } \\
\text { n Users }\end{array}$ & $\begin{array}{c}\text { Berha } \\
\text { sil }\end{array}$ \\
\hline 6 & $\begin{array}{l}\text { Klik } \\
\text { Add }\end{array}$ & $\begin{array}{l}\text { Halama } \\
\mathrm{n} \text { Users }\end{array}$ & $\begin{array}{l}\text { Menam } \\
\text { bah } \\
\text { User }\end{array}$ & $\begin{array}{c}\text { Berha } \\
\text { sil }\end{array}$ \\
\hline 7 & $\begin{array}{l}\text { Klik } \\
\text { Edit }\end{array}$ & $\begin{array}{l}\text { Halama } \\
\text { n Users }\end{array}$ & $\begin{array}{l}\text { Menge } \\
\text { dit User } \\
\text { yang } \\
\text { sudah } \\
\text { ada }\end{array}$ & $\begin{array}{c}\text { Berha } \\
\text { sil }\end{array}$ \\
\hline 8 & $\begin{array}{l}\text { Klik } \\
\text { Cancl } \\
e \\
\end{array}$ & $\begin{array}{l}\text { Halama } \\
\text { n Users }\end{array}$ & $\begin{array}{l}\text { Halama } \\
\mathrm{n} \\
\text { Utama }\end{array}$ & $\begin{array}{c}\text { Berha } \\
\text { sil }\end{array}$ \\
\hline 9 & $\begin{array}{l}\text { Klik } \\
\text { Delete }\end{array}$ & $\begin{array}{l}\text { Halama } \\
\text { n Users }\end{array}$ & $\begin{array}{l}\text { Mengh } \\
\text { apus } \\
\text { User }\end{array}$ & $\begin{array}{c}\text { Berha } \\
\text { sil }\end{array}$ \\
\hline $\begin{array}{l}1 \\
0\end{array}$ & $\begin{array}{l}\text { Klik } \\
\text { Pesan }\end{array}$ & $\begin{array}{l}\text { Halama } \\
\text { n daftar } \\
\text { penump } \\
\text { ang dan } \\
\text { kendara } \\
\text { an }\end{array}$ & $\begin{array}{l}\text { Halama } \\
\mathrm{n} \\
\text { Golong } \\
\text { an }\end{array}$ & $\begin{array}{c}\text { Berha } \\
\text { sil }\end{array}$ \\
\hline $\begin{array}{l}1 \\
1\end{array}$ & $\begin{array}{l}\text { Klik } \\
\text { Hapus }\end{array}$ & $\begin{array}{l}\text { Halama } \\
\text { n daftar } \\
\text { penump }\end{array}$ & $\begin{array}{l}\text { Mengh } \\
\text { apus } \\
\text { Data }\end{array}$ & $\begin{array}{c}\text { Berha } \\
\text { sil }\end{array}$ \\
\hline
\end{tabular}




\begin{tabular}{|c|c|c|c|c|}
\hline & & $\begin{array}{l}\text { ang dan } \\
\text { kendara } \\
\text { an }\end{array}$ & & \\
\hline $\begin{array}{l}1 \\
2\end{array}$ & $\begin{array}{l}\text { Klik } \\
\text { Refres } \\
h\end{array}$ & $\begin{array}{l}\text { Halama } \\
\text { n daftar } \\
\text { penump } \\
\text { ang dan } \\
\text { kendara } \\
\text { an }\end{array}$ & $\begin{array}{l}\text { Memua } \\
\mathrm{t} \text { ulang } \\
\text { data }\end{array}$ & $\begin{array}{c}\text { Berha } \\
\text { sil }\end{array}$ \\
\hline $\begin{array}{l}1 \\
3\end{array}$ & $\begin{array}{l}\text { Klik } \\
\text { Edit }\end{array}$ & $\begin{array}{l}\text { Halama } \\
\text { n daftar } \\
\text { penump } \\
\text { ang dan } \\
\text { kendara } \\
\text { an }\end{array}$ & $\begin{array}{l}\text { Menge } \\
\text { dit Data }\end{array}$ & $\begin{array}{c}\text { Berha } \\
\text { sil }\end{array}$ \\
\hline $\begin{array}{l}1 \\
4\end{array}$ & $\begin{array}{l}\text { Klik } \\
\text { Batal }\end{array}$ & $\begin{array}{l}\text { Halama } \\
\text { n daftar } \\
\text { penump } \\
\text { ang dan } \\
\text { kendara } \\
\text { an }\end{array}$ & $\begin{array}{l}\text { Halama } \\
\mathrm{n} \\
\text { Utama }\end{array}$ & $\begin{array}{c}\text { Berha } \\
\text { sil }\end{array}$ \\
\hline 1 & (2) & (3) & (4) & (5) \\
\hline $\begin{array}{l}1 \\
5\end{array}$ & $\begin{array}{l}\text { Klik } \\
\text { Filter }\end{array}$ & $\begin{array}{l}\text { Halama } \\
\text { n daftar } \\
\text { penump } \\
\text { ang dan } \\
\text { kendara } \\
\text { an }\end{array}$ & $\begin{array}{l}\text { Mengur } \\
\text { utkan } \\
\text { Data }\end{array}$ & $\begin{array}{c}\text { Berha } \\
\text { sil }\end{array}$ \\
\hline $\begin{array}{l}1 \\
6\end{array}$ & $\begin{array}{l}\text { Klik } \\
\text { Penu } \\
\text { mpan } \\
\text { g }\end{array}$ & $\begin{array}{l}\text { Halama } \\
\mathrm{n} \\
\text { Golong } \\
\text { an }\end{array}$ & $\begin{array}{l}\text { Halama } \\
\mathrm{n} \\
\text { Jumlah } \\
\text { Tiket } \\
\text { Penum } \\
\text { pang } \\
\text { Pejalan } \\
\text { Kaki }\end{array}$ & $\begin{array}{c}\text { Berha } \\
\text { sil }\end{array}$ \\
\hline $\begin{array}{l}1 \\
7\end{array}$ & $\begin{array}{l}\text { Klik } \\
\text { Kenda } \\
\text { raan }\end{array}$ & $\begin{array}{l}\text { Halama } \\
\mathrm{n} \\
\text { Golong } \\
\text { an }\end{array}$ & $\begin{array}{l}\text { Halama } \\
\mathrm{n} \quad \text { Gol } \\
\text { Kendar } \\
\text { aan }\end{array}$ & $\begin{array}{c}\text { Berha } \\
\text { sil }\end{array}$ \\
\hline 8 & $\begin{array}{l}\text { Klik } \\
\text { Batal }\end{array}$ & $\begin{array}{l}\text { Halama } \\
\mathrm{n}\end{array}$ & $\begin{array}{l}\text { Halama } \\
\text { n daftar }\end{array}$ & $\begin{array}{c}\text { Berha } \\
\text { sil }\end{array}$ \\
\hline
\end{tabular}




\begin{tabular}{|c|c|c|c|c|}
\hline & & $\begin{array}{l}\text { Golong } \\
\text { an }\end{array}$ & $\begin{array}{l}\text { penump } \\
\text { ang dan } \\
\text { kendara } \\
\text { an }\end{array}$ & \\
\hline $\begin{array}{l}1 \\
9\end{array}$ & $\begin{array}{l}\text { Klik } \\
\text { Save }\end{array}$ & $\begin{array}{l}\text { Halama } \\
\mathrm{n} \\
\text { Jumlah } \\
\text { Tiket } \\
\text { Penum } \\
\text { pang } \\
\text { Pejalan } \\
\text { Kaki }\end{array}$ & $\begin{array}{l}\text { Halama } \\
\mathrm{n} \\
\text { Pemesa } \\
\text { nan } \\
\text { Penum } \\
\text { pang }\end{array}$ & $\begin{array}{c}\text { Berha } \\
\text { sil }\end{array}$ \\
\hline $\begin{array}{l}2 \\
0\end{array}$ & $\begin{array}{l}\text { Klik } \\
\text { Cancl } \\
e\end{array}$ & $\begin{array}{l}\text { Halama } \\
\mathrm{n} \\
\text { Jumlah } \\
\text { Tiket } \\
\text { Penum } \\
\text { pang } \\
\text { Pejalan } \\
\text { Kaki }\end{array}$ & $\begin{array}{l}\text { Halama } \\
\mathrm{n} \text { daftar } \\
\text { penump } \\
\text { ang dan } \\
\text { kendara } \\
\text { an }\end{array}$ & $\begin{array}{c}\text { Berha } \\
\text { sil }\end{array}$ \\
\hline $\begin{array}{l}2 \\
1\end{array}$ & $\begin{array}{l}\text { Klik } \\
\text { Save }\end{array}$ & $\begin{array}{l}\text { Halama } \\
\mathrm{n} \\
\text { Golong } \\
\text { an } \\
\text { Kendar } \\
\text { aan }\end{array}$ & $\begin{array}{l}\text { Halama } \\
\mathrm{n} \\
\text { Pemesa } \\
\text { nan } \\
\text { Kendar } \\
\text { aan }\end{array}$ & $\begin{array}{c}\text { Berha } \\
\text { sil }\end{array}$ \\
\hline $\begin{array}{l}2 \\
2\end{array}$ & $\begin{array}{l}\text { Klik } \\
\text { Cancl } \\
e\end{array}$ & $\begin{array}{l}\text { Halama } \\
\mathrm{n} \\
\text { Golong } \\
\text { an } \\
\text { Kendar } \\
\text { aan }\end{array}$ & $\begin{array}{l}\text { Halama } \\
\mathrm{n} \text { daftar } \\
\text { penump } \\
\text { ang dan } \\
\text { kendara } \\
\text { an }\end{array}$ & $\begin{array}{c}\text { Berha } \\
\text { sil }\end{array}$ \\
\hline $\begin{array}{l}2 \\
3\end{array}$ & $\begin{array}{l}\text { Klik } \\
\text { Refres } \\
h\end{array}$ & $\begin{array}{l}\text { Halama } \\
\mathrm{n} \\
\text { Golong } \\
\text { an } \\
\text { Penum } \\
\text { pang }\end{array}$ & $\begin{array}{l}\text { Memua } \\
\mathrm{t} \text { ulang } \\
\text { golonga } \\
\mathrm{n} \\
\text { penump } \\
\text { ang }\end{array}$ & $\begin{array}{c}\text { Berha } \\
\text { sil }\end{array}$ \\
\hline $\begin{array}{l}2 \\
4\end{array}$ & $\begin{array}{l}\text { Klik } \\
\text { Exit }\end{array}$ & $\begin{array}{l}\text { Halama } \\
\mathrm{n} \\
\text { Golong } \\
\text { an } \\
\text { Penum } \\
\text { pang }\end{array}$ & $\begin{array}{l}\text { Halama } \\
\mathrm{n} \\
\text { Pemesa } \\
\text { nan } \\
\text { Penum } \\
\text { pang }\end{array}$ & $\begin{array}{c}\text { Berha } \\
\text { sil }\end{array}$ \\
\hline $\begin{array}{l}2 \\
5\end{array}$ & $\begin{array}{l}\text { Klik } \\
\text { Save }\end{array}$ & $\begin{array}{l}\text { Halama } \\
\mathrm{n} \\
\text { Pemesa } \\
\text { nan } \\
\text { Penum } \\
\text { pang }\end{array}$ & $\begin{array}{l}\text { Halama } \\
\mathrm{n} \text { daftar } \\
\text { penump } \\
\text { ang dan } \\
\text { kendara } \\
\text { an }\end{array}$ & $\begin{array}{c}\text { Berha } \\
\text { sil }\end{array}$ \\
\hline
\end{tabular}




\begin{tabular}{|c|c|c|c|c|}
\hline $\begin{array}{l}2 \\
6\end{array}$ & $\begin{array}{l}\text { Klik } \\
\text { Cancl } \\
e\end{array}$ & $\begin{array}{l}\text { Halama } \\
\mathrm{n} \\
\text { Pemesa } \\
\text { nan } \\
\text { Penum } \\
\text { pang }\end{array}$ & $\begin{array}{l}\text { Halama } \\
\mathrm{n} \text { daftar } \\
\text { penump } \\
\text { ang dan } \\
\text { kendara } \\
\text { an }\end{array}$ & $\begin{array}{c}\text { Berha } \\
\text { sil }\end{array}$ \\
\hline $\begin{array}{l}2 \\
7\end{array}$ & Klik > & $\begin{array}{l}\text { Halama } \\
\mathrm{n} \\
\text { Pemesa } \\
\text { nan } \\
\text { Penum } \\
\text { pang }\end{array}$ & $\begin{array}{l}\text { Halama } \\
\mathrm{n} \\
\text { Pemesa } \\
\text { nan } \\
\text { Penum } \\
\text { pang 1 }\end{array}$ & $\begin{array}{c}\text { Berha } \\
\text { sil }\end{array}$ \\
\hline $\begin{array}{l}2 \\
8\end{array}$ & Klik < & $\begin{array}{l}\text { Halama } \\
\mathrm{n} \\
\text { Pemesa } \\
\text { nan } \\
\text { Penum } \\
\text { pang }\end{array}$ & $\begin{array}{l}\text { Halama } \\
\mathrm{n} \\
\text { Pemesa } \\
\text { nan } \\
\text { Penum } \\
\text { pang } 2\end{array}$ & $\begin{array}{l}\text { Berha } \\
\text { sil }\end{array}$ \\
\hline $\begin{array}{l}2 \\
9\end{array}$ & $\begin{array}{l}\text { Klik } \\
\text { Save }\end{array}$ & $\begin{array}{l}\text { Halama } \\
\mathrm{n} \\
\text { Pemesa } \\
\text { nan } \\
\text { Kendar } \\
\text { aan }\end{array}$ & $\begin{array}{l}\text { Halama } \\
\mathrm{n} \text { daftar } \\
\text { penump } \\
\text { ang dan } \\
\text { kendara } \\
\text { an }\end{array}$ & $\begin{array}{l}\text { Berha } \\
\text { sil }\end{array}$ \\
\hline $\begin{array}{l}3 \\
0\end{array}$ & $\begin{array}{l}\text { Klik } \\
\text { Cancl } \\
e\end{array}$ & $\begin{array}{l}\text { Halama } \\
\mathrm{n} \\
\text { Pemesa } \\
\text { nan } \\
\text { Kendar } \\
\text { aan }\end{array}$ & $\begin{array}{l}\text { Halama } \\
\mathrm{n} \text { daftar } \\
\text { penump } \\
\text { ang dan } \\
\text { kendara } \\
\text { an }\end{array}$ & $\begin{array}{l}\text { Berha } \\
\text { sil }\end{array}$ \\
\hline $\begin{array}{l}3 \\
1\end{array}$ & $\begin{array}{l}\text { Klik } \\
\text { Menu }\end{array}$ & $\begin{array}{l}\text { Halama } \\
\mathrm{n} \\
\text { Utama }\end{array}$ & $\begin{array}{l}\text { Menu } \\
\text { Keluar } \\
\text { dan } \\
\text { Logout }\end{array}$ & $\begin{array}{c}\text { Berha } \\
\text { sil }\end{array}$ \\
\hline $\begin{array}{l}3 \\
2\end{array}$ & $\begin{array}{l}\text { Klik } \\
\text { Logou } \\
t\end{array}$ & $\begin{array}{l}\text { Halama } \\
\mathrm{n} \\
\text { Utama }\end{array}$ & $\begin{array}{l}\text { Halama } \\
\text { n Login }\end{array}$ & $\begin{array}{l}\text { Berha } \\
\text { sil }\end{array}$ \\
\hline $\begin{array}{l}3 \\
3\end{array}$ & $\begin{array}{l}\text { Klik } \\
\text { Kelua } \\
\mathrm{r}\end{array}$ & $\begin{array}{l}\text { Halama } \\
\mathrm{n} \\
\text { Utama }\end{array}$ & $\begin{array}{l}\text { Aplikas } \\
\mathrm{i} \\
\text { Tertutu } \\
\mathrm{p}\end{array}$ & $\begin{array}{l}\text { Berha } \\
\text { sil }\end{array}$ \\
\hline
\end{tabular}

Sumber : Hasil Analisa, 2018

Dari data tersebut, maka dapat diketahui bahwa aplikasi manifes penumpang dan kendaraan yang direncanakan dapat dioperasikan sesuai dengan yang direncanakan.

\section{KESIMPULAN}

Sebelum menerapkan aplikasi manifes penumpang dan kendaraan yang direncanakan, maka kita harus memperhatikan dampak atau keuntungan yang akan diperoleh apabila aplikasi 
manifes ini diterapkan di Pelabuhan Penyeberangan Batulicin. Berikut Perbandingan antara sistem pendataan manifes secara manual dengan sistem pendataan manifes dengan menggunakan menggunakan aplikasi manifes penumpang dan kendaraan:

\section{Perbandingan Sistem Manual dengan Sistem Aplikasi}

\begin{tabular}{|c|c|c|}
\hline NO & Sist & $\begin{array}{c}\text { Sistem Dengan } \\
\text { Menggunakan } \\
\text { Aplikasi } \\
\end{array}$ \\
\hline 1. & $\begin{array}{l}\text { Tidak } \\
\text { melakukan } \\
\text { pencatatan } \\
\text { daftar } \\
\text { penumpang dan } \\
\text { kendaraan } \\
\text { angkutan } \\
\text { penyeberangan } \\
\text { sesuai Peraturan } \\
\text { Menteri } \\
\text { Perhubungan } \\
\text { Nomor } \\
\text { Tahun } 2016 \\
\text { tentang Daftar } \\
\text { Penumpang Dan } \\
\text { Kendaraan } \\
\text { Angkutan } \\
\text { Penyeberangan, } \\
\text { sehingga pihak } \\
\text { Pengelolah } \\
\text { Pelabuhan tidak } \\
\text { memiliki data } \\
\text { yang pasti. }\end{array}$ & $\begin{array}{l}\text { Memuat data } \\
\text { penumpang dan } \\
\text { kendaraan sesuai } \\
\text { dengan } \\
\text { ketentuan pada } \\
\text { Peraturan } \\
\text { Menteri } \\
\text { Perhubungan } \\
\text { Nomor 25 Tahun } \\
\text { 2016 tentang } \\
\text { Daftar } \\
\text { Penumpang Dan } \\
\text { Kendaraan } \\
\text { Angkutan } \\
\text { Penyeberangan, } \\
\text { sehingga pihak } \\
\text { pengelola } \\
\text { pelabuhan } \\
\text { memiliki data } \\
\text { yang pasti } \\
\text { mengenai } \\
\text { jumlah dan data } \\
\text { penumpang serta } \\
\text { kendaraan. }\end{array}$ \\
\hline 2. & $\begin{array}{l}\text { Proses } \\
\text { pembelian tiket } \\
\text { lebih cepat } \\
\text { karena tidak } \\
\text { dilakukannya } \\
\text { pengisian } \\
\text { biodata } \\
\text { penumpang dan } \\
\text { kendaraan. } \\
\end{array}$ & $\begin{array}{l}\text { Proses } \\
\text { pembelian tiket } \\
\text { lebih lambat } \\
\text { karena petugas } \\
\text { melakukan } \\
\text { pengisian data } \\
\text { penumpang dan } \\
\text { kendaraan pada } \\
\text { aplikasi. }\end{array}$ \\
\hline 3. & $\begin{array}{l}\text { Tidak memiliki } \\
\text { arsip daftar } \\
\text { penumpang dan } \\
\text { kendaraan. }\end{array}$ & $\begin{array}{l}\text { Memudahkan } \\
\text { dalam } \\
\text { pengarsipan } \\
\text { daftar } \\
\text { penumpang dan } \\
\text { kendaraan. }\end{array}$ \\
\hline 4. & $\begin{array}{l}\text { Tidak dapat } \\
\text { memantantau } \\
\text { secara pasti }\end{array}$ & \begin{tabular}{lr}
\multicolumn{2}{c}{ Dapat memantau } \\
jumlah & tiket \\
yang & terjual \\
\end{tabular} \\
\hline
\end{tabular}




\begin{tabular}{|l|lr|l|}
\hline & jumlah tiket & maupun tiket \\
yang terjual & $\begin{array}{l}\text { maupun tiket } \\
\text { yang tersisa di } \\
\text { yang masih } \\
\text { tersisa di loket. }\end{array}$ & $\begin{array}{l}\text { loket melalui } \\
\text { nomor seri tiket } \\
\text { yang terdata } \\
\text { dalam aplikasi. }\end{array}$ \\
\hline 5. & $\begin{array}{l}\text { Tidak dapat } \\
\text { memastikan } \\
\text { tiket yang sudah } \\
\text { terjual tidak } \\
\text { dapat dijual } \\
\text { kembali. }\end{array}$ & $\begin{array}{l}\text { Dapat } \\
\text { memastikan } \\
\text { tiket yang sudah } \\
\text { terjual agar tidak } \\
\text { dapat dijual } \\
\text { kembali. }\end{array}$ \\
\hline
\end{tabular}

Sumber : Hasil Analisa, 2018

Berdasarkan tabel diatas, dapat disimpulkan bahwa terdapat kekurangan dan kelebihan pada masing-masing sistem pembelian tiket penumpang dan kendaraan di pelabuhan Penyeberangan Batulicin.

\section{REFERENSI}

1. Direktorat Jendral Perhubungan darat, Pengembangan angkutan Sungai,Danau dan Penyeberangan, Jakarta 2006

2. Keputusan Menteri Perhubungan No KM 32 , Tahun 2001, Tentang Penyelenggaraan angkutan Penyeberangan.

3. Keputusan Direktur Jendral Perhubungan Darat No: SK.73/AP005/DRJD/2003 Tahun 2003, tentang Persyaratan minimal Angkutan Penyeberangan.

4. International Maritime Organization, IMO and RO RO Safety, London 1997.

5. Undang Undang Republik Indonesia Nomor 17 Tahun 2008 tentang Pelayaran

6. Nurgiyantoro, Burhan, Gunawan dan Marzuki, 2000, Statistik Terapan Untuk IlmuIlmu Sosial, Yogyakarta: Gadja Mada University Press.

7. Rakhmat, Jalaludin, 1999, Metode Penelitian Komunikasi, Bandung : PT Remaja Rosda Karya.

8. Sugiyono, 2001, Metode Penelitian Bisnis, Bandung : CV Alfabeta

9. Suharsimi, Arikanto, 2000, Manajemen Penelitian, Jakrata : Rineka Cipta

10. Bruton M.J (1985); Introduction to Transportation Planning,Hutchinson Melbourne

11. Kanafani,Adib,(1983);Transportation Demand Analysis, Mc GrawHill Book Company,New York.

12. Miro,Fidel (2005); Perencanaan Transportasi, Erlangga,Jakarta

13. Bambang.S (2009),Modelling and System Simulation:Theory,Aplication, And Sample Programs in Language C. Bandung: Imformatika. 
Vol. 12 No. 1 (2021): Jurnal Penelitian Sekolah Tinggi Transportasi Darat

14. Schwier., \& Misanchuk.(1994),Interactive Multimedia Instruction, London. 